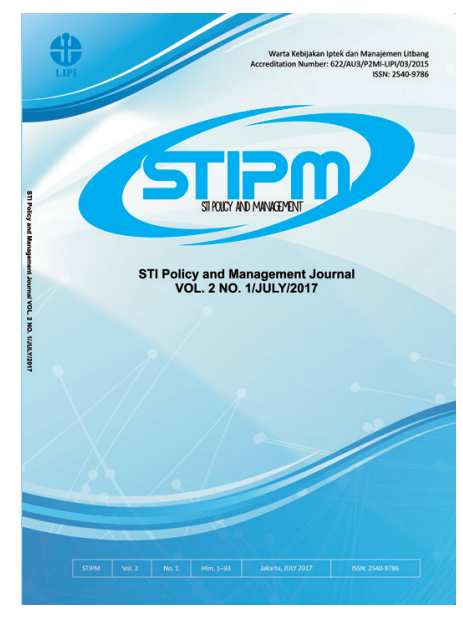

Journal of STI Policy and Management

Publication details, including instructions for authors and subscription information: http://www.stipmjournal.org/

\title{
Developing the Marine and Fisheries Industry in Pangandaran using a Bioecoregion-Based Technopark Framework
}

\author{
Atikah Nurhayati ${ }^{1}$ and Agus Heri Purnomo ${ }^{2}$ \\ ${ }^{1}$ Faculty of Fisheries and Marine Science, Padjadjaran University, Indonesia \\ ${ }^{2}$ Agency for Marine and Fisheries Research and Development, Indonesia
}

Version of record first published: 15 July 2017

To cite this article: Nurhayati, A., Purnomo, A.H. (2017). Developing the Marine and Fisheries Industry in Pangandaran using a Bioecoregion-Based Technopark Framework. Journal of STI Policy and Management, 2(1), 43-52

To link to this article: http://dx.doi.org/10.14203/STIPM.2017.72

ISSN 2540-9786 (Print); ISSN 2502-5996 (online)

Accreditation Number: 622/AU3/P2MI-LIPI/03/2015

Full terms and conditions of use: https://creativecommons.org/licenses/by-nc-sa/4.0/

You are free to:

- Share : copy and redistribute the material in any medium or format

- Adapt : remix, transform, and build upon the material

- The licensor cannot revoke these freedoms as long as you follow the license terms.

Under the following terms:

Attribution - You must give appropriate credit, provide a link to the license, and indicate if changes were made. You may do so in any reasonable manner, but not in any way that suggests the licensor endorses you or your use.

$\$$ NonCommercial - You may not use the material for commercial purposes.

(2) ShareAlike - If you remix, transform, or build upon the material, you must distribute your contributions under the same license as the original.

No additional restrictions - You may not apply legal terms or technological measures that legally restrict others from doing anything the license permits.

Notices:

- You do not have to comply with the license for elements of the material in the public domain or where your use is permitted by an applicable exception or limitation.

- No warranties are given. The license may not give you all of the permissions necessary for your intended use. For example, other rights such as publicity, privacy, or moral rights may limit how you use the material.

- If you copy the dataset merely to extract the uncopyrightable data elements would not need permission to do so. However, if you republish the full dataset or using the copyrightable data layers require a permission from PAPPIPTEK-LIPI. 


\title{
JOURNAL OF SCIENCE, TECHNOLOGY AND INNOVATION POLICY AND MANAGEMENT (STIPM JOURNAL), Volume 02, Number 01, July 2017
}

\author{
FOREWORD by EDITOR-in-CHIEF
}

We are very pleased to inform readers that Journal of Science, Technology and Innovation Policy and Management (STIPM Journal) Vol. 2, No. 1, July 2017 is now ready for public reading.

The STIPM Journal is an online research journal managed by the Center for Science and Technology Development Studies at the Indonesian Institute of Sciences (PAPPIPTEK-LIPI). As a peer-reviewed journal, the STIPM Journal provides free access to research thoughts, innovation, and original discoveries mostly aimed at scholars.

In this edition, the STIPM Journal contains six articles dealing with science, technology and innovation policy and management written by scholars from Japan, Australia, and Indonesia.

The first article is entitled "Innovation Process of Natural Resource-based Firms in Four ASEAN Economies: A SEM Approach" by Masatsugu Tsuji, Hiroki Idota, Yasushi Ueki, and Teruyuki Bunno. Using a structural equation model (SEM), this paper discusses the innovation process in natural resourcebased industries in Vietnam, Indonesia, the Philippines, and Thailand in comparison to other assembling and processing industries by focusing how factors affect product as well as process innovation.

The second article is written by Noel Taylor-Moore, entitled "The Innovative Policy Options for Coastal Fisheries Economic Development: A Case of Kwandang Bay Coastal Ecosystem”. This article uses a policy innovation framework in the context of STI inputs and a multi-level perspective (MLP), selects a potential site in which a fisheries economic development hub would be implemented, and performs a SWOT analysis of the selected site as a hub.

Erman Aminullah, Trina Fizzanty, Karlina Sari, Rizka Rahmaida, and Qinan M. B. Soesanto present the third article, "Interactive Learning for Upgrading and Growth: Case of Indonesian Fishery Firms." This article discusses an interactive learning model for upgrading and growth in Indonesian fishery firms using the case of fish processing and aquaculture (shrimp). The model suggests that the dynamics of upgrading and growth through interactive learning will be able to continue in a stable manner as constraints from limiting elements are eased through: combating illegal fishing; encouraging interaction with universities; shifting to higher added-value products; increasing institutional support for global trading; preventing shrimp diseases; and providing infrastructure, business facilities, and regulation information.

The fourth article, entitled "Developing the Marine and Fisheries Industry in Pangandaran using a Bioecoregion-based Technopark Framework", is written by Atikah Nurhayati and Agus H. Purnomo. This article discusses how to establish a marine and fisheries technopark in Pangandaran. By using gap and SWOT analysis, it was found that particular recommendations for improvement should be made, 
the existing bioecoregional environment and development variables in Pangandaran would support the development of a marine and fisheries technopark.

The fifth article, entitled "Development of National Technology Audit Policy", is presented by Subiyanto. This article discusses the concept of a national technology auditing policy, particularly with regard to infrastructure requirements, and with emphasis on technical regulation effectiveness and implementation tool readiness. This article discusses setting a policy agenda by discussing the governance aspect of national technology auditing.

The final article is written by Anugerah Yuka Asmara and Toshio Mitsufuji with the title "Photovoltaic Development from the New Order Era to the Reform Era in Indonesia: From a Technological Innovation System Perspective”. This article discusses the phenomena of PV development between the New Order era and the Reform era using a technological innovation system (TIS) approach. This paper concludes that PV projects and technology could not be developed en masse without intervention from the government in both the New Order era and the Reform era.

We also would like to thank the authors, editors, and reviewers who have worked very hard for this edition. We hope that all the articles featured in this edition proves useful to the reader.

Jakarta, 16 July 2017

Editor-in-Chief 



\section{JOURNAL OF STI POLICY AND MANAGEMENT}

Volume 2, Number 1, July 2017

\section{LIST OF CONTENTS}

Innovation Process of Natural Resource-based Firms in Four ASEAN Economies: A SEM Approach

Masatsugu Tsuji, Hiroki Idota, Yasushi Ueki, and Teruyuki Bunno

The Innovative Policy Options for Coastal Fisheries Economic Development: A Case of Kwandang

Bay Coastal Ecosystem

Noel Taylor-Moore

Interactive Learning for Upgrading and Growth: Case of Indonesian Fishery Firms

Erman Aminullah, Trina Fizzanty, Karlina Sari, Rizka Rahmaida, and Qinan M.B. Soesanto

Developing the Marine and Fisheries Industry in Pangandaran using a Bioecoregion-based Technopark Framework

Atikah Nurhayati and Agus Heri Purnomo

Development of National Technology Audit Policy

Subiyanto.

Photovoltaic Development from the New Order Era to the Reform Era in Indonesia:

From a Technological Innovation System Perspective

Anugerah Yuka Asmara and Toshio Mitsufuji. 


\title{
Developing the Marine and Fisheries Industry in Pangandaran Using a Bioecoregion-Based Technopark Framework
}

\author{
Atikah Nurhayati ${ }^{1}$, Agus Heri Purnomo ${ }^{2}$ \\ ${ }^{1}$ Faculty of Fisheries and Marine Science, Padjadjaran University, Indonesia \\ ${ }^{2}$ Agency for Marine and Fisheries Research and Development, Indonesia
}

\begin{tabular}{|c|c|}
\hline ARTICLE INFO & ABSTRACT \\
\hline $\begin{array}{l}\text { Article History: } \\
\text { Received : } 13 \text { November } 2016 \\
\text { Revised : } 09 \text { May } 2017 \\
\text { Accepted : 06 July } 2017 \\
\text { Available online : } 15 \text { July } 2017\end{array}$ & $\begin{array}{l}\text { From a bioecoregional point of view, Pangandaran is land } \\
\text { water mass with a strong ecological connectivity which is also } \\
\text { characterized by the dominance of marine and fisheries resource } \\
\text { potential. In this region, there are a number of development } \\
\text { variables that exist and can be leveraged to transform these natural }\end{array}$ \\
\hline $\begin{array}{l}\text { Keywords: } \\
\text { Marine and fisheries industry } \\
\text { Pangandaran } \\
\text { Technopark } \\
\text { Roadmap } \\
\text { Bioecoregion }\end{array}$ & $\begin{array}{l}\text { resources into an advanced industry, which in turn can sustain } \\
\text { the region's economy. Recognizing such a premise, this study } \\
\text { analyzes these variables in more detail as associated with efforts } \\
\text { to accelerate the establishment of a strong economy tsupported by } \\
\text { a marine and fisheries industry in Pangandaran. The technopark } \\
\text { concept is taken as the main reference for the development of } \\
\text { the industry, while gap analysis is used as the study's primary } \\
\text { methodological approach. Primary and secondary data were } \\
\text { collected through literature study, discussion, consultation, field } \\
\text { visits, and a focus group discussion, and were used in the gap } \\
\text { analysis, followed by a SWOT analysis. Based on the research, it } \\
\text { is concluded that Pangandaran's existing bioecoregional setting } \\
\text { as well as the available development variables are conducive to } \\
\text { the development of a marine and fisheries technopark, as long } \\
\text { as certain actions for improvement are carried out. A proposal to } \\
\text { operationalize such improvements as suggested by the result of } \\
\text { this research is demonstrated in a roadmap, presented in the final } \\
\text { section of this paper. }\end{array}$ \\
\hline
\end{tabular}

C2017 PAPPIPTEK-LIPI All rights reserved

\section{INTRODUCTION}

The enactment of the Law Number 21/2012 signified the birth of Pangandaran District in West Java Province. According to this law, Pangandaran District is delineated by territorial lines covering

* Corresponding Author.

E-mail: atikah.nurhayati@unpad.ac.id
10 sub-districts that once were those of Ciamis District. These are Parigi, Cijulang, Cimerak, Cigugur, Langkaplancar, Mangunjaya, Padaherang, Kalipucang, Pangandaran and Sidamulih. Parigi was selected as the newborn district's capital. The total area of Pangandaran is 168,509 $\mathrm{Ha}$, of which $67,340 \mathrm{Ha}$ is marine. This marine 
area has a coastal line of $91 \mathrm{~km}$ (Pangandaran Development Planning Agency, 2015). Pangandaran waters are part of Indonesia's Indian Ocean Fisheries Management Zone, which encompasses the waters from the western tip of Sumatra to the south coast of Java. Such an administrative draft has made Pangandaran a unique bioregional setting, where marine areas hold important potential resources and where two sectors, namely tourism and capture fisheries, coexist.

Thus far, there have been a number of studies regarding bioecoregions focusing on development in Pangandaran, including by Nurhayati and Purnomo (2014). Results from those studies generally show that marine resources in Pangandaran can be used to sustain the economic development of the district and neighboring areas through the exploitation of two marine-based sectors, namely marine tourism and capture fisheries.

Owing to the significance of the marine areas in its bioecoregional setting, Pangandaran has developed an economy that focuses on these two sectors. As reported, these two sectors contribute significantly not only to the economy of Pangandaran area, but also to the economy of neighboring regions (Nurhayati \& Purnomo, 2014). And this, of course, provides a strong motive to keep the development of Pangandaran District on its current path, which positions marine tourism and marine capture fisheries as the two prime movers.

In facing the growing challenges, however, Pangandaran should not only rely on its natural resource potential; rather, it must consider other important variables, such as human resources, the availability of capital and the transfer of technological information, all of which are necessary to increase the competitiveness of the district. In line with this, examining regional economic development would be the relevant approach in this context. According to Arsyad (1999), regional economic development is a process by which local governments and communities manage existing resources, and a pattern of partnership is formed between local governments and the private sector to create a new employment and stimulate the development of economic growth.

Development of the tourism sector in Pangandaran may emulate the premise put forward by Yoeti (2006), wherein tourism is referred to as an alternative economic sector with the capability to accelerate efforts to tackle poverty. Butler (1993) proposes a concept of tourism which remains viable over an indefinite period of time and does not degrade or alter the environment. Furthermore, Ziegler, Dearden, and Rollins (2012) warn that tourism activities targeting marine wildlife should be managed in a sustainable manner, both from a social and biological perspective.

Meanwhile, a study by the Ministry of Marine Affairs and Fisheries (2017) revealed that the approach needed to improve added value in the industry is to develop the marine processing industry. The study also found that this can be achieved through the cooperation and support of all stakeholders, which include central and local governments as well as private and $R \& D$ institutions, including universities and research and development centers.

None of these studies, however, deal with the issue of conflict that arises from development of the two sectors. There is little effort to reconcile all positive aspects of the two sectors while mitigating impacts from developing the two sectors at the same time. These impacts are social, biological, and economic ones.

Recognizing the above concerns, the 'science and technology park' (STP) concept, in which we can establish effective industrial systems that can accommodate all determining social, biological as well as economic objectives, becomes relevant. A technopark can be defined literally as industrial zone which is developed and run based on science and technology. The technopark constitutes an infrastructure development that facilitates interactions process between the scientific industry, community, and the consumer. A technopark is aimed at exploring potential resources and developing the existing ones.

A technopark or sciencepark can be defined as an integrated region that unites industry actors, including consumers, research and entrepreneurship centers, banking, and government centers, in one location, enabling a faster and more efficient flow of information, technology, expertise, and transaction. According to Havila (1996), science 
parks in this context can be seen either as an actor in a relationship between two organisations, for example between science park and company belonging to the science park, or as an intermediary.

As a matter of fact, there are many commonly used terms for a science park, such as 'science city', 'technopark', 'business park', 'technology corridor', 'technology zone', and many others. No matter what it is called, however, an STP always provides a link between scientific bodies and industry. Through an STP, ideas and innovation are advanced to promote an effective value-adding process, while at the same time maintain the resources' future services. Therefore, a technopark as considered in this study is an industrial system in a delineated area in Pangandaran District, of which tourism and fisheries are positioned as the primary platforms, and where harmony among those sectors are advanced at all stages of development.

The purpose of this study is to analyze the developing marine and fisheries industry in Pangandaran following a bioecoregion-based technopark framework. Research regarding practices around the world is referred to in this study's analysis, including those of new technology-based firms (Lindelöf \& Löfsten, 2002).

The technopark is an area which functions as a place to innovate $R \& D$ activities, as well as a means of nonformal learning. It can work closely with a university so research results can be developed and can be introduced to the users.

With the presence of a technopark, the industry may produce innovations derived from R\&D activities in the technopark itself so that it will automatically generate employment. The existing conditions in Pangandaran require the tourism and fisheries sectors to collaborate, for example, in ecotourism, where the coastal zone management is part of the technopark.

There seem to have been few attempts to test whether such an effect actually occurs (Beaumont, 2001). In any event, this mechanism would not yield a net conservation gain unless three criteria were all met simultaneously: i) there was a net marginal increase in political activism, due specifically to the ecotourism experience; ii) such activism was effective in improving actual conservation outcomes; and iii) such gains outweighed the aggregate environmental impacts of all clients.

\section{METHODOLOGY}

This study uses a descriptive and quantitative approach. Data used in this study include primary and secondary data, which were collected primarily through interviews with purposively sampled respondents and the snowball sampling technique. Respondents represent the most relevant stakeholders, namely the local government, community institutions, academia, and private entrepreneurs. The data were analyzed using 'strength-weakness-opportunity-threat' (SWOT) analysis and gap analysis.

According to Saaty (1987), internal factors (strengths and weaknesses) and external factors (opportunities and threats) can be analyzed to obtain strategies. These strategies may fall into one of the following: i) strength-opportunity (S-O) strategies; ii) weakness-opportunity (W-O) strategies; iii) strength-threat (S-T) strategies and iv) weakness-threat (W-T) strategies. Furthermore, weights and ranks are assigned to the reading of SWOT values (Saaty, 1987; Rangkuti, 2001). In this study, weights and ranks were drawn from the views of selected experts. These experts represented relevant stakeholders including marine and fisheries officers, scientists and managers. Data from these experts were averaged to obtain values to be used in the analysis.

Gap analysis in this paper is used to compare current conditions of identified factors with targeted ones in order to identify areas in need of improvement with regard to compliance to the relevant standards. This analytical tool represents a formal means to identify and correct gaps between desired levels and actual levels of performance.

\section{RESULTS AND DISCUSSION}

\section{A. SWOT analysis}

As suggested in the background section, the development of the marine and fisheries industry in Pangandaran is to be designed using a technopark concept which considers the existing 
bioecoregional setting. Therefore, the analysis was carried out as follows. In SWOT analysis, Strength, Weakness, Opportunity, and Threat factors were identified during fieldwork. Strength factors were: i) S1: the bioecoregional potential of natural resources; ii) S2: the human resource potential; iii) S3: the existence of universitybased R\&D facilities; iv) S4: the existence of local productive and effective community institutions; and v) S5: the existence of supporting local government policy. Weakness factors were: i) W1: the decrease in quality of natural resources; ii) W2: inadequate innovation facilities for the development of marine tourism and the fisheries industry; iii) W3: inadequate skill for marine tourism and fishery innovation; iv) W4: the lack of incubators necessary for developing sound marine and fishery entrepreneurship; and v) W5: the lack of effective financial institutions. Table 1 shows the weight, ranking, and respective scores for these strength and weakness factors.

As shown in Table 1, the highest score among the strength factors is that of the bioecoregional natural resource potential (S1), i.e. 0.60, followed by university-based R\&D facilities (S3) (0.44), human resource potential (0.36), local productive community institutions (0.30) and supporting local government policies $(0.27)$. The highest score among the weakness factors is the score of inadequate innovation facilities (W2), i.e. 0.44 , followed by the lack of incubators (W4) (0.40), the lack of effective financial institutions (W5) (0.32), inadequate skill for innovation (W3)
(0.27), and decrease in quality of natural resource (W1) (0.16).

The regional Pangandaran infrastructure has not been be able to accommodate a variety of interests related to industrial development based on marine resources and fisheries to maritime tourism activities (i.e. ecotourism) and value-added processing of fishery products. The intermediary role of technopark can also concern the relationships of start-up companies with other entities like customers, suppliers, financers, and innovation partners for fisheries food processing. A technopark means an interaction between stakeholders and innovation from the results of R\&D activity, which extracts the potential of the fishery resources and marine tourism. The purpose of governance is so that the value of benefits derived from the fisheries and marine sources, environmental services, and space in Pangandaran and surrounds is optimal for stakeholders.

Table 2 shows the weight, ranking, and respective scores of the opportunity $(\mathrm{O})$ and threat $(\mathrm{T})$ factors. Opportunity factors were: i) O1: Government policies on the technopark, ii) $\mathrm{O} 2$ : Entrepreneurial advancement program for marine tourism and fishing industry, iii) O3: Market opportunities for fishery products, iv) O4: Improved public comprehension of and business opportunities in bioecoregional tourism and the fishing industry, v) O5: Formal and informal educational cooperation. Meanwhile, threat factors were: i) T1: Ecoregional spatial conflicts between

Table 1.

Strategy Analysis-Matrix of Internal Factors

\begin{tabular}{|c|c|c|c|c|}
\hline \multicolumn{2}{|c|}{ Internal factors } & Weight & Ranking & Score \\
\hline \multicolumn{5}{|c|}{ Strengths } \\
\hline 1. & Bioecoregional natural resource potential (S1) & 0.15 & 4 & 0.60 \\
\hline 2. & Human resource potential (S2) & 0.09 & 4 & 0.36 \\
\hline 3. & University-based R\&D facilities (S3) & 0.11 & 4 & 0.44 \\
\hline 4. & Local productive community institutions (S4) & 0.10 & 3 & 0.30 \\
\hline 5. & Supporting local government policies (S5) & 0.09 & 3 & 0.27 \\
\hline \multicolumn{5}{|c|}{ Weaknesses } \\
\hline 1. & Decrease in quality of natural resources (W1) & 0.08 & 2 & 0.16 \\
\hline 2. & Inadequate innovation facilities (W2) & 0.11 & 4 & 0.44 \\
\hline 3. & Inadequate skill to carry out innovation (W3) & 0.09 & 3 & 0.27 \\
\hline 4. & Lack of incubators (W4) & 0.10 & 4 & 0.40 \\
\hline 5. & Lack of effective financial institutions (W5) & 0.08 & 4 & 0.32 \\
\hline Tot & & 1.00 & & 5.15 \\
\hline
\end{tabular}


marine tourism and the fishing industry, ii) T2: Market competition between marine tourism and the fishing industry, iii) T3: Social and political vulnerability, iv) T4: Lack of coordination among sectors, and v) T5: Low investment in the fisheries industry.

As shown in Table 2, the highest score among other opportunity factors is that of government policies on the technopark (O1), i.e. 0.56, followed by the entrepreneurial advancement program for marine tourism and the fishing industry $(\mathrm{O} 2)(0.48)$, market opportunities for fisheries products $(\mathrm{O} 3)(0.30)$, improved public comprehension of and business opportunities in bioecoregional tourism and the fishing industry (O4) (0.30), and formal and informal educational cooperation $(\mathrm{O} 5)(0.24)$. The highest score among the threat factors is that of ecoregional spatial conflicts between marine tourism and the fishing industry (T1), i.e. 0.44 , followed by market competition between marine tourism and the fishing industry (T2) (0.40), low investment in fisheries industry (T5) (0.40), social and political vulnerability (T3) (0.24), and the lack of coordination among sectors (T4) (0.21).

Based on the SWOT analysis (Figure 1), it can be concluded that the ideal strategy for the development of a marine and fisheries technopark in Pangandaran would be the one shown in the Quadrant 1. Pangandaran would be able to combine its strengths and best opportunities; this is the growth-oriented strategy, executed through the optimization of the bioecoregional potential of its natural resources and an improvement in human resource potential. The consistency of this result is shown by its alpha Cronbach value of 0.977 , meaning that the result is reliable.

\section{B. Gap analysis}

To develop an operational framework for the development of a Pangandaran technopark, the following gap analysis compares the current conditions of a number of variables with their targeted ones, these variables being: i) infrastructure; ii) a fisheries technical services unit; iii) development of fisheries techology; iv) a fisheries business incubator; and v) fisheries government policy. Table 3 summarizes this study's assessment of these variables.

Based on a focus group discussion, the followings can be concluded.

Within the infrastructure factor, the basic infrastructure subfactor has a gap value of $44.45 \%$,

Table 2.

Strategy Analysis-Matrix of External Factors

\begin{tabular}{|c|c|c|c|}
\hline External factors & Weight & Ranking & Score \\
\hline \multicolumn{4}{|l|}{ Opportunities } \\
\hline 1. Government policies on the technopark (O1) & 0.14 & 4 & 0.56 \\
\hline $\begin{array}{l}\text { 2. Entrepreneurial advancement program for marine } \\
\text { tourism and fishing industry (O2) }\end{array}$ & 0.12 & 4 & 0.48 \\
\hline 3. Market opportunities for fishery products (O3) & 0.10 & 3 & 0.30 \\
\hline $\begin{array}{l}\text { 4. Improved public comprehension of and business } \\
\text { opportunities in bioecoregional tourism and the fishing industry } \\
\text { (O4) }\end{array}$ & 0.10 & 3 & 0.30 \\
\hline 5. Formal and informal educational cooperation (05) & 0.08 & 3 & 0.24 \\
\hline \multicolumn{4}{|l|}{ Threats } \\
\hline $\begin{array}{l}\text { 1. Ecoregional spatial conflicts between marine tourism and the } \\
\text { fishing industry (T1) }\end{array}$ & 0.11 & 4 & 0.44 \\
\hline $\begin{array}{l}\text { 2. Market competition between marine tourism and the fishing } \\
\text { industry (T2) }\end{array}$ & 0.10 & 4 & 0.40 \\
\hline 3. Social and political vulnerability (T3) & 0.08 & 3 & 0.24 \\
\hline 4. Lack of coordination among sectors (T4) & 0.07 & 3 & 0.21 \\
\hline 5. Low investment in the fisheries industry (T5) & 0.10 & 4 & 0.40 \\
\hline Total & 1 & & 5.26 \\
\hline
\end{tabular}




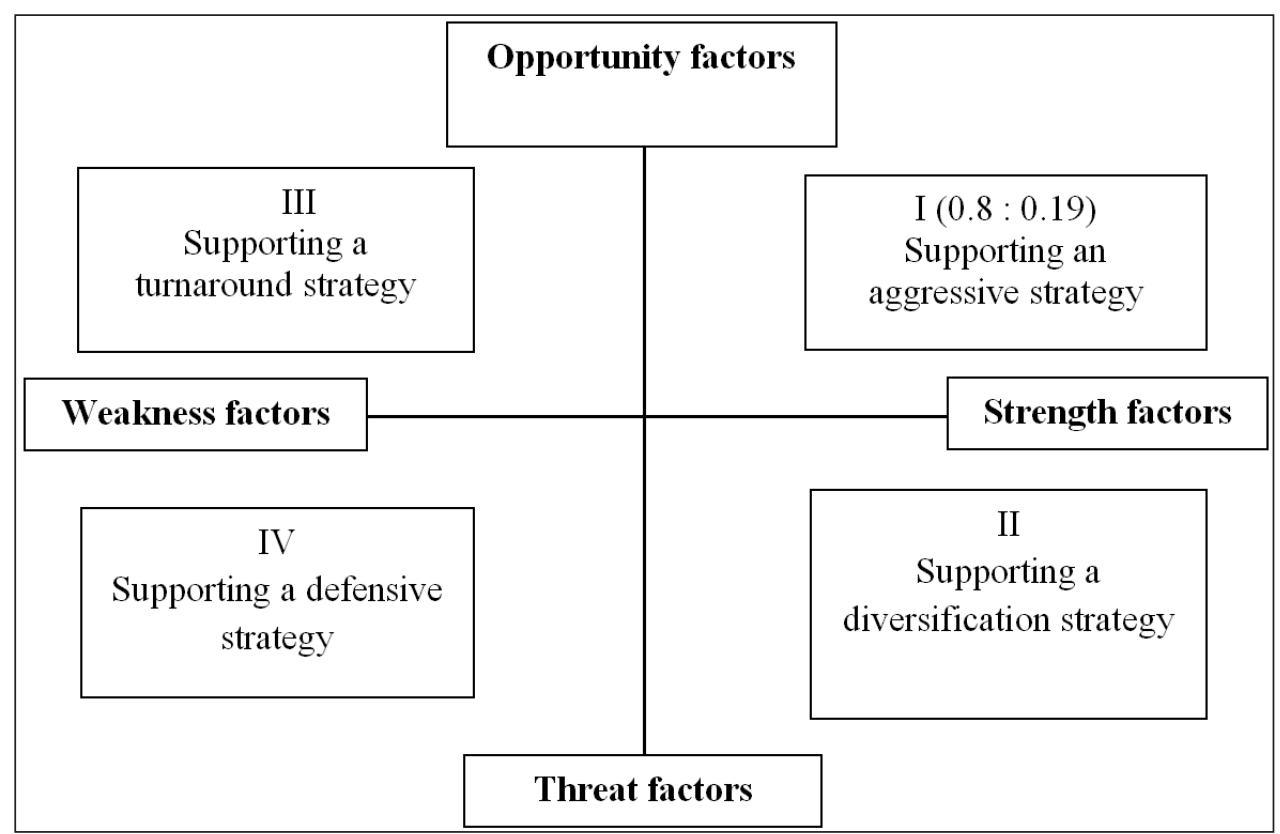

Figure 1. SWOT Matrix-Development Strategies for the Marine and Fisheries Industry in Pangandaran using a Bioecoregion-based Technopark Framework

Table 3.

Gap Analysis for a Bioecoregional Fisheries and Marine Technopark in Pangandaran

\begin{tabular}{|c|c|c|c|c|c|}
\hline & Factor & Sub-factor & Current & Future & Gap (\%) \\
\hline \multirow[t]{3}{*}{1} & Infrastructure & Basic infrastructure & 25 & 45 & 44.45 \\
\hline & & Technology infrastructure & 20 & 35 & 42.86 \\
\hline & & Scientific infrastructure & 20 & 45 & 55.00 \\
\hline \multirow[t]{3}{*}{2} & Fisheries technical service unit & Training & 25 & 55 & 54.55 \\
\hline & & Apprenticeship & 24 & 45 & 46.67 \\
\hline & & Information & 30 & 55 & 45.45 \\
\hline \multirow[t]{3}{*}{3} & Development of fisheries techology & Technological design & 27 & 60 & 55.00 \\
\hline & & Product prototypes & 25 & 60 & 61.54 \\
\hline & & Technology adopter & 30 & 65 & 53.85 \\
\hline \multirow[t]{3}{*}{4} & Fisheries business incubators & Business service center & 35 & 75 & 53.33 \\
\hline & & Financial institutions & 30 & 60 & 50.00 \\
\hline & & Attitude & 25 & 60 & 58.33 \\
\hline \multirow[t]{3}{*}{5} & Government policy & Access to licensing & 27 & 50 & 46.00 \\
\hline & & Regulation favoring local products & 30 & 65 & 53.85 \\
\hline & & Special credit schemes & 28 & 67 & 58.21 \\
\hline
\end{tabular}

with $42.86 \%$ for technology infrastructure, and $55 \%$ for scientific infrastucture.

Within the fisheries technical services unit factor, the training subfactor has a gap value of $54.55 \%$, with $46.67 \%$ for apprenticeship and $45.45 \%$ for information.

Within the development of fisheries technology factor, the technological design subfactor has a gap value of $55 \%$, with $61.54 \%$ for product prototypes and $53.85 \%$ for technology adopter.
Within the fisheries business incubator factor, the business service center subfactor has a gap value of $53.33 \%$, with $50 \%$ for financial institutions and $58.33 \%$ for attitude and fisheries product value.

Finally, within the government policy factor, the facilities and access to licensing subfactor has a gap value of $46 \%$, with $53.85 \%$ for regulation in favor to local products and $58.21 \%$ for special credit schemes for fisheries and marine industry. 
Gap analysis shows that an operational framework for a Pangandaran technopark will have to address several factors and subfactors. Improvement of basic infrastructure will be needed to optimize marine tourism and capture fisheries. In capture fisheries, fish processes need to be improved through the introduction of applied technologies and the support of technology facilities, and all targeting an increase in added value. Improvement in the quality of human resources is also needed, and this can be carried out through periodic formal and informal training.

The industrial development should be carried out through designed steps and prototyping, which ideally should be adopted as standard practice by the people of Pangandaran. Following from this, young entrepreneurs who have the full support of government policies will emerge. A prerequisite to enable the above is the simultaneous improvement of human resources. Therefore, entrepreneurship will grow and local resource utilization will take place.

Based on the results of the gap analysis, the following is a suggested roadmap for the development of the marine and fisheries indus- try in Pangandaran, using a bioecoregion-based technopark framework.

Figure 3 shows the proposed path of development in Pangandaran. It is based on the results of the analysis and is meant to optimize the potential from the bioecoregional setting so that existing conditions can be improved toward the set goals. Through this path, relevant innovations are introduced through business incubations, which are an important part of a technopark framework. A marine tourism-based technopark in Pangandaran is an important element in the regional economic development process. In general, such a technopark will generate larger contribution of the tourism sector in a country with an open economy.

Ecotourism is also a principal source of employment at the Pangandaran; it is a laborintensive industry where hard labor is replaced by capital and equipment. Therefore, the state is interested in the tourism sector as a source of employment. As rephrased from Spilance (1987), ecotourism is traveling to relatively undisturbed or uncontaminated natural areas with the specific objectives of studying, admiring, and enjoying

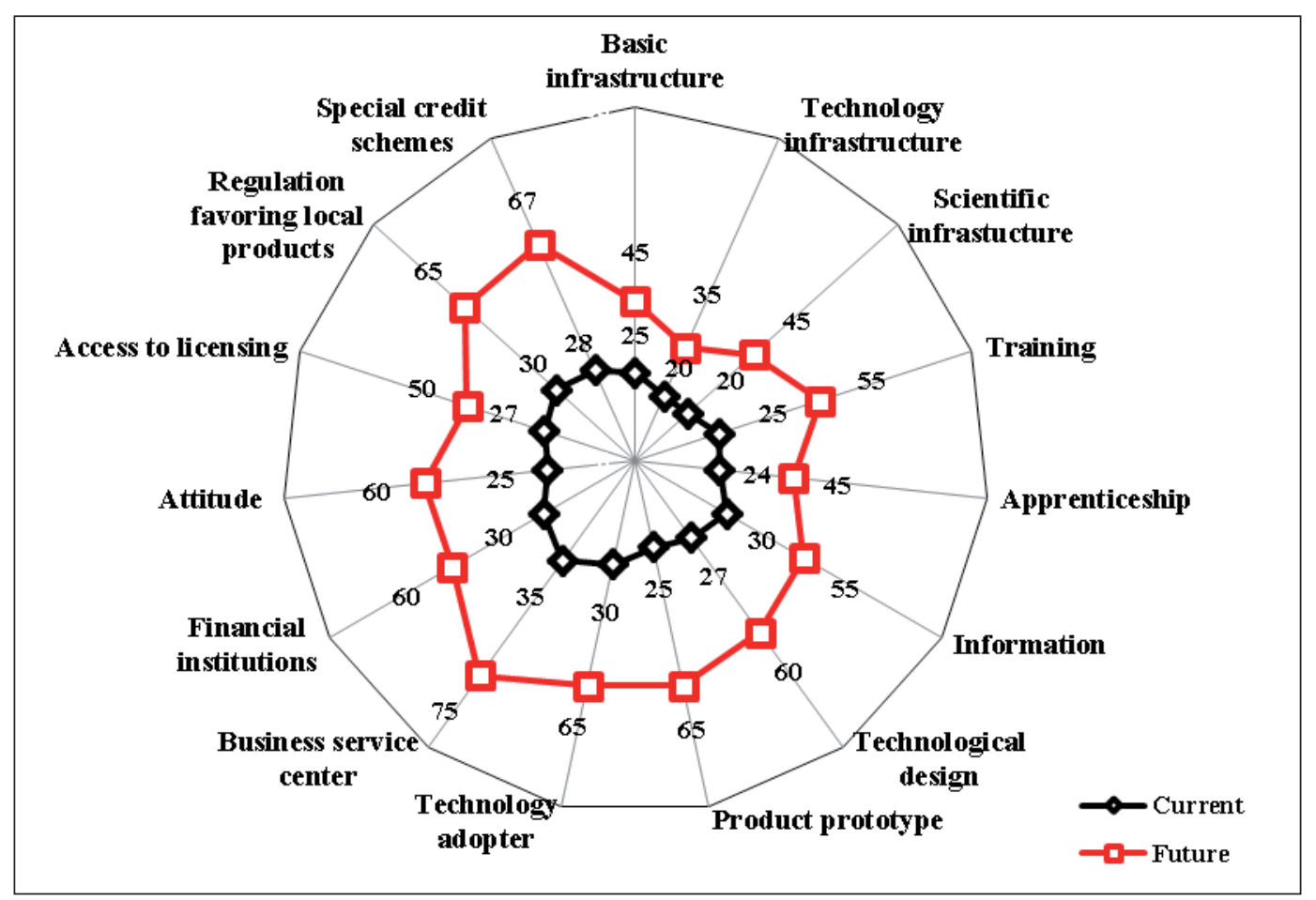

Figure 2. Gap Analysis

Developing marine and fisheries industry in Pangandaran using a bioecoregion-based technopark framework 


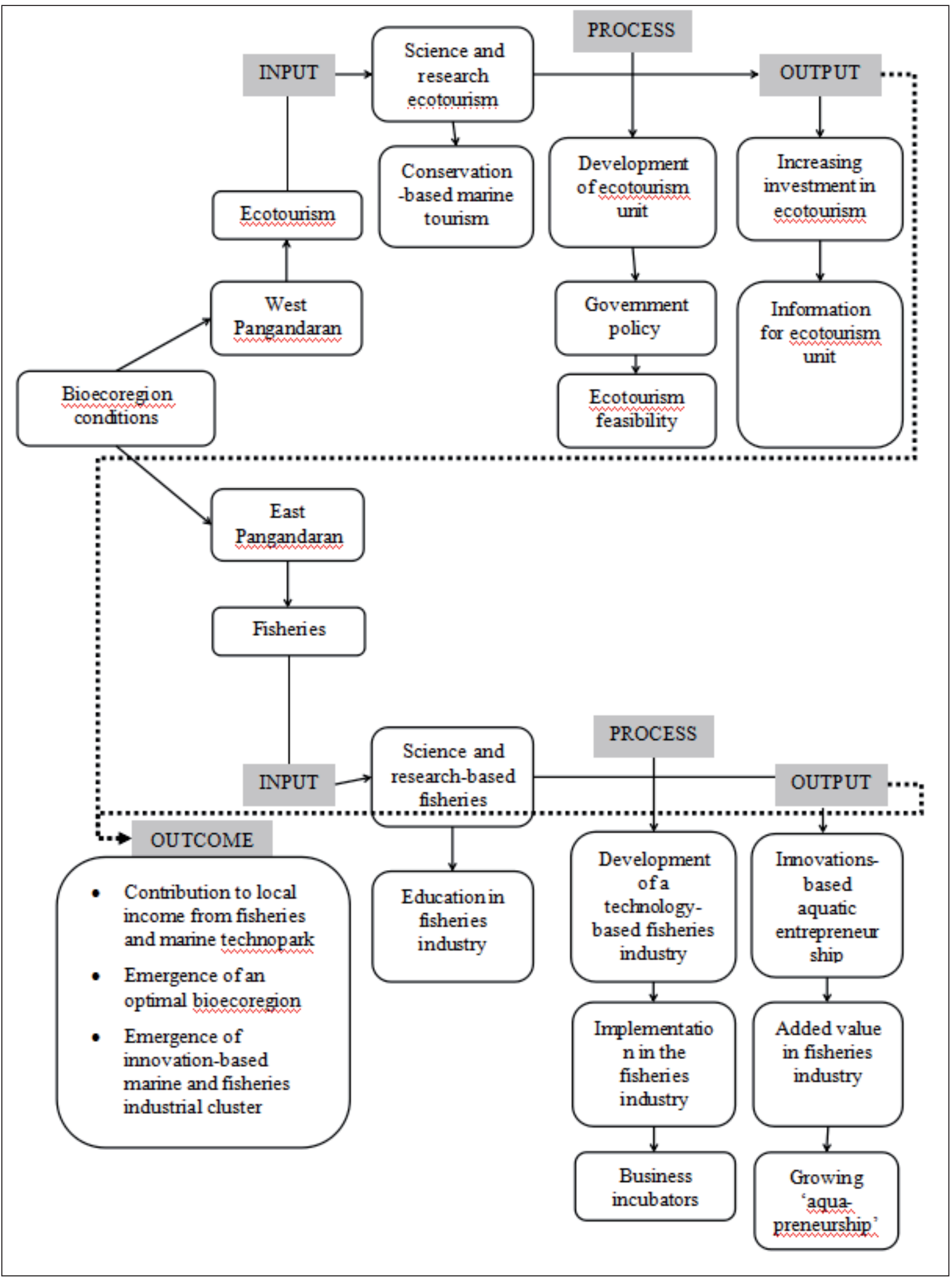

Figure 3. Developing the Marine and Fisheries Industry in Pangandaran Using a Bioecoregion-based Technopark Framework 
the scenery and its wild plants and animals, as well as any existing cultural manifestations (both past and present) found in these areas. Dependent on using natural resources in a relatively undeveloped state, ecotourism is based on natural features like scenic views, wild rivers, pristine forests, and abundant wildlife and necessitates a high-quality maintenance of these resources. Ecotourism is advocated for its theoretical harmonious relationship between the natural and human environment (Boo, 1987). Protected areas are often considered as destinations because of their 'naturalness'.

Attention should be given to the characteristics of human activity, commodities developed and environmental factors in the Pangandaran area, as well as to those of the intention surrounding the construction of a fisheries and marine technopark. These factors include but are not limited to land activities associated with fishing, fisheries production, post-harvest fisheries strategies, the fishing industry, fish processing industry, the buyers and sellers of fish products, research, education, fisheries-related business consulting, the provision of financial services, business incubator units, 'demo' mini-plants, display technology options, product standards, meeting facilities, facility certifications, competence, and public infrastructure to transfer the added value to the economy.

Business incubators function as conductors of guidance and management consulting in the field of marine tourism and fishery processing industry development, including relating to access to technology use as well as the development of business plans and capitalization assistance efforts. A technopark is a professionally managed regional aim to improve the welfare of its members and to support innovation to improve the competitiveness of the industries and institutions that are involved.

\section{CONCLUSION}

The study concludes that Pangandaran's existing bioecoregional settings as well as the available development variables are conducive to facilitate the development of a marine and fisheries technopark in the area. To materialize this, the most relevant strategy that should be applied is one of aggressive growth, i.e. the growth-oriented strategy. This strategy can be carried out through a number of actions, which focus on improvements in infrastructure, fisheries technical service unit, and government policy, as well as the establishment of fisheries business incubators.

\section{REFERENCES}

Arsyad, L. (1999). Introduction to planning economic regional developing. First Editions. Yogyakarta: BPFE.

Beaumont, N. (2001). Ecotourism and the conservation ethic: Recruiting the uninitiated or preaching to the converted? Journal of Sustainable Tourism, 9(4), 317-341. (http://dx.doi. org/10.1080/09669580108667405).

Boo, E. (1987). Ecotourism: The potentials and pitfalls: Country case studies. WWF.

Buckley, R. (2002). Tourism ecocertification in the International Year of Ecotourism. Journal of Ecotourism, 1(2-3), 197-203. (http://dx.doi. org/10.1080/14724040208668126).

Butler, R. W. (1993). Tourism: An evolutionary perspective. In J. G. Nelson, R. Butler \& G. Wall (Eds.), Tourism and sustainable development: Monitoring, planning, managing (No. 37, pp 27-44). Waterloo: University of Waterloo.

Havila, V. (1996). International business-relationship triads: A study of the changing role of the intermediating actor. (Doctoral dissertation), Retrieved from the Department of Business Studies, Uppsala University (No. 64).

Lindelöf, P., \& Löfsten, H. (2002). Growth, management and financing of new technology-based firms - assessing value-added contributions of firms located on and off Science Parks. Omega, 30(3), 143-154. (https://doi.org/10.1016/ S0305-0483(02)00023-3).

Ministry of Marine Affairs and Fisheries. (2017). Capture Fisheries Statistics 2010.Accessed form http://ledhyane.lecture.ub.ac.id/files/2015/02/ DJPT_2011-Statistik-Perikanan-TangkapIndonesia-2010.pdf. on 14 June 2017. Jakarta: Ministry of Marine Affairs and Fisheries.

Nurhayati, A., \& Purnomo, A. H. (2014). A Case study on sustainability analysis of fisheries in Pangandaran, West Java Province. Journal of Agricultural Science and Technology B, 321. (https:// doi.org/10.17265/2161-6264/2014.04B.010). 
Pangandaran Development Planning Agency (Bappeda). (2015). Profil Pangandaran (Pangandaran profile). Pangandaran: Bappeda Pangandaran. Retrieved 1 September 2016 from http://www.pangandarankab.go.id/profilpangandaran/.

Rangkuti, F. (2001). SWOT analysis: Business case technique. Jakarta: Gramedia Pustaka Utama.

Saaty, R. W. (1987). The analytic hierarchy process and SWOT analysis- what it is and how it is used. Mathematical Modeling, 9, 161-178.

Siswanto, A. (2015). Eco-tourism development strategy Baluran National Park in the regency of Situbondo, East Java, Indonesia. International Journal of Evaluation and Research in Education, 4(4), 185-195.

Spilance, J. (1987). Tourism economy: History and its prospects. Jakarta: Kanisius.

Westhead, P., \& Storey, D. J. (1995). Links between higher education institutions and high technology firms. Omega, 23(4), 345-360.
Xu, J., Lue, Y., Chen, L., \& Liu, Y. (2009). Contribution of tourism development to protected area management: Local stakeholder perspectives. International Journal of Sustainable Development \& World Ecology, 16(1), 30-36. (http://dx.doi. org/10.1080/13504500902757189).

Yoeti, O. A. (2006). Pariwisata budaya masalah dan solusinya (Cultural tourism problems and its solution). Jakarta: Pradnya Paramita Press.

Ziegler, J., Dearden, P., \& Rollins, R. (2012). But are tourists satisfied? Importance-performance analysis of the whale shark tourism industry on Isla Holbox, Mexico. Tourism Management, 33(3), 692-701.

\section{Legislation}

Law No. 18/2002 on a National System for the Research, Development and Application of Science and Technology. 